\title{
Hasil pemeriksaan CT scan pada penderita stroke non hemoragik di Bagian Radiologi FK Unsrat/SMF Radiologi RSUP Prof. Dr. R. D. Kandou Manado periode Agustus 2015 - Agustus 2016
}

\author{
${ }^{1}$ Christian Elim \\ ${ }^{2}$ Vonny Tubagus \\ ${ }^{2}$ Ramli Hadji Ali \\ ${ }^{1}$ Kandidat Skripsi Fakultas Kedokteran Universitas Sam Ratulangi Manado \\ ${ }^{2}$ Bagian Radiologi/Fakultas Kedokteran Universitas Sam Ratulangi Manado \\ RSUP Prof. Dr. R. D. Kandou, Manado \\ Email: tian.elim@yahoo.com
}

\begin{abstract}
CT-scan is used to analyze the structures of specific body parts, mainly to confirm the diagnosis of non-hemorrhagic stroke. Stroke is a neurological deficit that occurs suddenly and caused by the interruption of blood flow to the brain. The symptoms are corresponding to the location of the stroke. This study was aimed to obtain the CT-scan examination of non-haemorrhagic stroke patients. This was a retrospective descriptive study using secondary data such as request letter and data of head CT-scan performed from August 2015 to August 2016. The results showed that there were 89 cases of non-hemorrhagic stroke. The majority were males (60 patients; 67\%), elderly $\geq 65$ years old ( 27 patients; $30 \%$ ), and location of lesion in the right hemisphere (38 patients; $43 \%$ ). Conclusion: In this study most patients diagnosed as non-hemorrhagic stroke with CT-scan were males, over 65 years old, and location of lesion in right hemisphere.
\end{abstract}

Keywords: non-haemorrhagic stroke, CT-scan

\begin{abstract}
Abstrak: CT scan digunakan untuk menganalisis struktur dalam dari beberapa bagian tubuh tertentu, antara lain untuk memastikan diagnosis dari stroke non hemoragik, Stroke merupakan suatu defisit neurologik yang terjadi secara tiba-tiba diakibatkan oleh adanya gangguan aliran darah ke otak dan gejala yang terjadi sesuai dengan lokasi dari stroke tersebut. Penelitian ini bertujuan untuk mengetahui hasil pemeriksaan CT scan pada penderita stroke non hemoragik. Jenis penelitian ialah deskriptif retrospektif dengan memanfaatkan data sekunder berupa lembar permintaan dan data hasil CT scan kepala yang dilaksanakan sejak Agustus 2015 sampai Agustus 2016. Hasil penelitian mendapatkan sebanyak 89 kasus didiagnosis stroke non-hemoragik dengan CT-scan, terbanyak ialah jenis kelamin laki-laki berjumlah 60 orang $(67 \%)$; golongan usia manula ( $\geq 65$ tahun) berjumlah 27 orang (30\%); dan lokasi lesi di hemisfer dekstra berjumlah 38 orang (43\%). Simpulan: Pada studi ini, majoritas pasien yang didiagnosis stroke non-hemoragik dengan CT-scan Berjenis kelamin laki-laki, usia $\geq 65$ tahun, dengan lokais lesi pada hemisfer kanan.
\end{abstract}

Kata kunci: stroke non hemoragik, CT-scan

CT-scan digunakan untuk menganalisis struktur dalam dari beberapa bagian tubuh tertentu seperti melihat trauma kepala, tumor, infark otak, pendarahan, dan sebagainya. Proses CT-scan ini tidak menyebabkan rasa sakit atau non invasif dan dapat menyediakan informasi yang sangat akurat tentang gambaran penyakit dari organ yang diperiksa untuk membantu menegakkan diagnosis dan penanganan lanjut. ${ }^{1}$

Menurut World Health Organization 
(WHO) definisi dari stroke adalah tandatanda klinis yang berkembang dengan cepat akibat gangguan fungsi otak fokal atau global, gejalanya dapat berlangsung selama 24 jam atau lebih, dan dapat menyebabkan kematian, Terjadinya stroke dikarenakan oleh gangguan aliran darah ke otak dengan tanda atau gejala sesuai dengan lokasi atau regio yang terganggu diakibatkan oleh infark serebri (stroke iskemik), pendarahan intraserebral atau pendarahan subarahnoid. ${ }^{2}$

Stroke merupakan suatu defisit neurologik yang terjadi secara tiba-tiba diakibatkan oleh adanya gangguan aliran darah ke otak. Terdapat dua jenis stroke yaitu stroke hemoragik dan stroke nonhemoragik. Stroke non-hemoragik disebut juga stroke iskemik (non-hemorrhagic stroke, NHS). Stroke iskemik dapat terjadi akibat terdapatnya sumbatan bekuan darah dalam pembuluh darah di otak atau arteri yang menuju ke otak; stroke jenis ini yang paling sering terjadi. ${ }^{3}$

Stroke dapat diakibatkan oleh beberapa faktor seperti usia. Usia merupakan faktor resiko yang paling penting bagi semua jenis stroke. Insiden stroke meningkat secara eksponensial dengan bertambahnya usia. Di Oxfordshire selama 1981-1986, tingkat insiden stroke pada kelompok usia 45-54 tahun ialah 57 kasus per 100.000 penduduk dan tahun 1987 pada kelompok usia 85 tahun ke atas. Berdasarkan jenis kelamin, insidens stroke di Amerika Serikat 270 per 100.000 pada laki-laki dan 201 per 100.000 pada perempuan. Di Denmark, insidens stroke 270 per 100.000 pada laki-laki dan 189 per 100.000 pada perempuan. Dari beberapa paparan di atas dapat dilihat bahwa laki-laki lebih banyak terkena stroke dari pada perempuan. ${ }^{4}$

Berdasarkan hasil Riskesdas tahun 2013, persentase kasus stroke tertinggi yang terdiagnosis tenaga kesehatan ialah usia 75 tahun keatas $(43,1 \%)$ dan terendah pada kelompok usia 15-24 tahun $(0,2 \%)$. Berdasarkan jenis kelamin laki-laki $(7,1 \%)$ lebih banyak dibandingkan perempuan $(6,8 \%)$. Berdasarkan data 10 besar penyakit terbanyak di Indonesia tahun 2013, Sulawesi Utara memiliki prevalensi kasus stroke tertinggi $(10,8 \%)$ sednagkan Papua yang terendah (2,3\%). Menurut Dinkes Provinsi Jawa Tengah, pada tahun 2012 kasus stroke hemoragik lebih tinggi daripada kasus stroke non-hemoragik. Kasus stroke hemoragik sebanyak 1.044 kasus dan 135 kasus untuk stroke nonhemoragik. ${ }^{5}$

Berdasarkan tingginya angka stroke terutama dengan adanya faktor risiko usia dan jenis kelamin maka penelitian ini bertujuan untuk mengetahui hasil CT-scan pada penderita stroke non-hemoragik di Bagian Radiologi FK Unsrat/SMF RSUP Prof. Dr. R. D. Kandou Manado.

\section{METODE PENELITIAN}

Jenis penelitian ini ialah deskriptif retrospektif dengan memanfaatkan data sekunder berupa lembar permintaan dan data hasil CT scan kepala yang terdapat di Bagian Radiologi Fakultas Kedokteran Unsrat/SMF Radiologi RSUP Prof. Dr. R. D. Kandou Manado selama periode Agustus 2015-Agustus 2016.

Populasi penelitian ialah semua lembaran permintaan CT-scan kepala dengan diagnosis stroke non-hemoragik di Bagian Radiologi Fakultas Kedokteran Unsrat/SMF Radiologi RSUP Prof. Dr. R. D. Kandou Manado periode Agustus 2015 Agustus 2016. Sampel penelitian harus memenuhi kriteria inklusi yaitu terbukti menderita stroke non-hemoragik berdasarkan hasil anamnesis, pemeriksaan fisik, dan pemeriksaan penunjang yang dilakukan oleh dokter maupun tenaga medis lainnya. Kriteria eksklusi yaitu hasil ekspertise yang menyatakan pasien normal, diagnosis bukan stroke non-hemoragik, dan data tidak lengkap. Variabel penelitian ialah hasil ekspertise pemeriksaan CT-scan stroke non-hemoragik yang didistribusi menurut jenis kelamin, kelompok umur dan lokasi lesi. Data diolah dengan menggunakan microsoft excel dan disajikan dalam bentuk teks dan tabel.

\section{HASIL PENELITIAN}

Berdasarkan hasil penelitian terhadap penderita stroke non-hemoragik pada 
periode Agustus 2015-Agustus 2016, dari 526 permintaan $\mathrm{CT}$-scan kepala dengan diagnosis cerebrovascular disease ischemic stroke (CVD SI) terdapat 136 lembar permintaan yang disertakan lembaran hasil. Dari lembaran permintaan yang disertakan hasil terdapat 89 yang dinyatakan stroke iskemik dan 47 yang dinyatakan normal, diagnosis bukan stroke non-hemoragik atau data tidak lengkap (Tabel 1).

Tabel 1. Distribusi pemeriksaan CT-scan dengan diagnosis CVD SI

\begin{tabular}{ccc}
\hline $\begin{array}{c}\text { Lembar permintaan } \\
\text { dan hasil }\end{array}$ & $\begin{array}{c}\text { Terdapat } \\
\text { infark }\end{array}$ & $\begin{array}{c}\text { Hasil } \\
\text { eksklusi }\end{array}$ \\
\hline 136 & $89(65 \%)$ & $47(35 \%)$ \\
\hline
\end{tabular}

Tabel 2 memperlihatkan dari 89 penderita stroke non-hemoragik pada periode Agustus 2015-Agustus 2016, didapatkan jumlah penderita laki-laki sebanyak 60 orang (67\%) sedangkan jumlah penderita perempuan sebanyak 29 orang $(33 \%)$.

Tabel 2. Distribusi berdasarkan jenis kelamin

\begin{tabular}{lcc}
\hline Jenis kelamin & n & \% \\
\hline Laki-laki & 60 & 67 \\
perempuan & 29 & 33 \\
Total & 89 & 100 \\
\hline
\end{tabular}

Tabel 3 memperlihatkan dari 89 orang penderita kasus stroke non-hemoragik periode Agustus 2015-Agustus 2016 yang terbanyak ialah kelompok usia $>65$ tahun.

Tabel 3. Distribusi berdasarkan kelompok usia

\begin{tabular}{lcc}
\hline Usia (tahun) & $\mathbf{n}$ & $\mathbf{\%}$ \\
\hline $0-5$ & 3 & 3 \\
$5-11$ & 1 & 1 \\
$12-16$ & 3 & 3 \\
$17-25$ & 3 & 3 \\
$26-35$ & 2 & 2 \\
$36-45$ & 11 & 12 \\
$46-55$ & 21 & 24 \\
$56-65$ & 18 & 20 \\
$>65$ & 27 & 30 \\
Total & 89 & 100 \\
\hline
\end{tabular}

Tabel 4 memperlihatkan dari hasil 89 kasus penderita stroke non-hemoragik pada periode Agustus 2015-Agustus 2016 berdasarkan distribusi lokasi hemisfer kanan berjumlah 38 penderita $(43 \%)$ dan hemisfer kiri berjumlah 31 penderita (35\%). Terdapat pula yang mengalami lesi di kedua sisi (bilateral) dengan jumlah 20 penderita $(22 \%)$.

Tabel 4. Distribusi berdasarkan lokasi lesi

\begin{tabular}{lcc}
\hline Lokasi & n & \% \\
\hline Hemisfer kanan & 38 & 43 \\
Hemisfer kiri & 31 & 35 \\
Bilateral & 20 & 22 \\
Total & 89 & 100 \\
\hline
\end{tabular}

\section{BAHASAN}

Pada penelitian ini ditemukan sebanyak 526 pasien yang melakukan pemeriksaan CT Scan dengan diagnosis stroke non-hemoragik di Bagian Radiologi FK. Unsrat/SMF Radiologi RSUP Prof. Dr. R. D. Kandou Manado periode Agustus 2015 - Agustus 2016.

Berdasarkan hasil penelitian, jumlah pasien yang melakukan CT-scan kepala dengan diagnosis CVD SI atau stroke non emoragik sebanyak 136 kasus; 89 kasus dinyatakan mengalami stroke iskemik atau terdapatnya infark dan sisanya yaitu 47 kasus dinyatakan keadaan normal atau memiliki ekspertisi berbeda dengan diagnosis. Stroke tidak bisa ditemukan pada pemeriksaan CT-scan dalam waktu 6 jam pertama kejadian. ${ }^{5}$

Berdasarkan hasil penelitian, dari 89 penderita yang melakukan pemeriksaan CT scan stroke non-hemoragik ditemukan jumlah penderita laki-laki (60 orang) lebih banyak daripada perempuan (29 orang). Hasil ini sejalan dengan yang dilaporkan dalam Riskesdas 2013 yaitu jenis kelamin laki-laki $(7,1 \%)$ lebih banyak dibandingkan perempuan (6,8\%). Diperkirakan bahwa insidensi stroke pada perempuam lebih rendah dibandingkan laki-laki akibat adanya estrogen yang berfungsi sebagai proteksi pada proses aterosklerosis, dan gaya hidup dari laki-laki seperti kebiasaan merokok mengakibatkannya lebih rentan terhadap kejadian stroke. ${ }^{6}$

Berdasarkan hasil penelitian, terdapat 
89 pasien yang dinyatakan menderita stroke non-hemoragik di Bagian Radiologi FK. Unsrat/SMF Radiologi RSUP Prof. Dr. R. D. Kandou Manado periode Agustus 2015Agustus 2016 dan terbagi atas beberapa kelompok usia. Kelompok usia dengan kasus terbanyak ialah kelompok usia $>65$ tahun yang sesuai dengan kriteria usia berdasarkan Depkes dengan jumlah 27 kasus (30\%), dan kelompok usia paling sedikit menurut Depkes ialah kelompok usia 5-11 tahun dengan jumlah 1 kasus (1\%). Terdapat beberapa faktor yang bisa menjadi risiko penyakit stroke, salah satu diantaranya ialah usia yang merupakan faktor risiko terpenting bagi semua jenis stroke. ${ }^{4}$ Usia merupakan faktor utama pembentukan ateroma yang menjadi faktor utama terjadinya stroke. Pembentukan ateroma terjadi seiring bertambahnya usia, dimana stroke paling sering terjadi pada usia $>65$ tahun, tetapi jarang terjadi pada usia <40 tahun. Dikatakan bahwa proses pembentukan ateroma tersebut dapat terjadi 20-30 tahun tanpa menimbulkan gejala. ${ }^{6}$

Stroke juga bisa terjadi pada anak-anak tetapi dengan penyebab yang agak berbeda daripada orang dewasa umumnya. Perbedaan yang paling mendasar dari stroke pada anak dengan stroke pada dewasa ialah faktor risiko stroke pada anak sangat beragam, misalnya, penyakit jantung kongenital dan sickle cell disease ialah penyebab stroke yang sering dijumpai pada anak. $^{7}$

Dari 89 kasus penderita stroke non hemoragik pada periode Agustus 2015Agustus 2016 berdasarkan distribusi lokasi didapatkan lokasi pada hemisfer kanan (43\%) lebih banyak daripada hemisfer kiri $(35 \%)$; juga terdapat yang mengalami lesi bilateral $(22 \%)$. Gejala-gejala stroke sangat berkaitan dengan bagian otak yang terganggu. Otak manusia terdiri atas beberapa bagian yaitu otak besar (serebrum), otak kecil (serebelum), dan batang otak. Otak besar terbagi atas bagianbagian besar yang disebut hemisfer, dan terdapat 2 hemisfer yaitu hemisfer kanan dan hemisfer kiri. Fungsi tubuh bagian kanan dikendalikan oleh hemisfer kiri sedangkan fungsi tubuh bagian kiri dikendalikan oleh hemisfer kanan. Otak juga terdiri atas lobi dengan fungsi masingmasing. ${ }^{8}$

Gangguan dari pembuluh darah otak yang memberikan pasokan darah ke lobus tertentu akan menyebabkan kelainan sesuai dengan fungsi lobus, seperti pada gangguan peredaran darah di lobus frontalis dan parietal akan menyebabkan gangguan gerak atau kelemahan otot dan rasa kebas pada kulit. Bila gangguan terdapat di serebelum maka akan terjadi gangguan gerak dan koordinasi serta keseimbangan. ${ }^{8}$

\section{SARAN}

Dengan angka kejadian stroke non hemoragik yang tinggi dan semakin meningkat di Indonesia khususnya Sulawesi Utara, bagi individu yang merasa memiliki faktor risiko stroke nonhemoragik tapi masih belum terkena stroke sebaiknya untuk mengubah gaya hidup ke gaya hidup yang sehat, seperti berhenti merokok, mengurangi berat badan, berhenti minum minuman keras, kurangi stres, kurangi makanan yang tinggi kolesterol dan lemak, dan mengatur pola makan yang sehat dan teratur seperti mengonsumsi buah-buahan atau sayur-sayuran, serta melakukan kontrol rutin untuk faktor risiko lainnya seperti hipertensi, diabetes melitus, penyakit jantung dan lain-lain.

Perlunya pengobatan dan penanganan yang tepat pada penderita stroke agar dapat kembali melaksanakan aktifitas fisik dan mental sehingga dapat mencegah kecacatan dan meningkatkan kualitas hidup.

\section{DAFTAR PUSTAKA}

1. CT Scan (Computerized tomography, CAT Scan). Available from: http://www.medicinenet.com/cat_scan/ article.htm

2. Mahmudah R. Left hemiparesis e.c. hemorrhagic stroke. Medula. 2014;2(4):70-9.

3. Yahya RC. Stroke non hemoragik - Gejala, diagnosa, dan terapi stroke iskemik. Artikel Kedokteran Jevuska. Available from: https: //www.jevuska.com /2007/04/11/gejala-diagnosa-terapi- 
stroke-non-hemoragik/

4. Riadi M. Kajian pustaka stroke non hemoragik. Available from: http://www.kajianpustaka.com/2013/07 /stroke-non-hemoragik.html.

5. Purwaningtiyas $\mathbf{P}$. Hubungan antara gaya hidup dengan kejadian stroke usia dewasa muda di RSUD Dr Moewardi Surakarta. Surakarta: Fakultas Kesehatan Universitas Muhammadiyah; 2014.

6. Japardi I. Patofisiologi stroke infark akibat tromboemboli. Medan: Bagian Bedah
Fakultas Kedokteran Universitas Sumatera Utara; p. 1-9.. Available from:

http://library.usu.ac.id.download/fk/bed ah-iskandar\%2520japardi31.pdf.

7. Rambe SA. Stroke pada Anak. Medan: Departemen Neurologi FK-USU/RSUP H. Adam Malik Medan, 2007

8. Pinzon R, Asanti L. Awas Stroke! Pengertian, gejala, tindakan, perawatan, dan pencegahan. Jakarta: Penerbit Andi, 2010; p. 15-7. 